DOI: http://doi.org/10.21009/JKKP.081.05

\title{
BUMBU TABUR TEMPE SEHAT, GURIH DAN PEDAS UNTUK KELUARGA
}

\author{
Dina Nurul Oktavianti ${ }^{1^{*}}$, Meddiati Fajri Putri ${ }^{1}$ \\ 1Program Studi Pendidikan Kesejahteraan Keluarga, Fakultas Teknik, Universitas Negeri \\ Semarang, Gunungpati 50229, Indonesia \\ *) E-mail: dinanurul987@gmail.com
}

\begin{abstract}
Abstrak
Salah satu fungsi keluarga adalah dapat memenuhi kebutuhan pangan dan gizi untuk keluarga. Kandungan protein dari bumbu tabur tempe dapat melengkapi kebutuhan gizi keluarga dengan harga relatif terjangkau. Bumbu tabur tempe merupakan bumbu yang fungsinya untuk memberikan rasa pelezat pada makanan atau jajanan. Rasa dan warna pada bumbu tabur bermacam- macam jenisnya menambah daya tarik tersendiri. Kandungan gizi pada serbuk cabai tersebut dijadikan penambahan dalam pembuatan bumbu tabur. Tujuan penelitian ini adalah untuk mengetahui penambahan serbuk cabai terhadap bumbu tabur tempe dengan prosentase $0 \%, 20 \%, 25 \%$, dan $30 \%$ ditinjau dari aspek aroma, warna, rasa, dan tekstur serta untuk mengetahui kandungan protein pada bumbu tabur. Metode pendekatan yang digunakan adalah metode eksperimen dikarenakan adanya perlakuan atau percobaan. Desain eksperimen yang digunakan adalah pretest-posttest control group desain. Hasil analis yang diperoleh kemudian dianalisa secara statistik. Untuk mengetahui kandungan gizi protein menggunakan metode Kjeldahl. Berdasarkan hasil uji kesukaan, sampel yang disukai masyarakat adalah sampel B dengan penambahan cabe $25 \%$ dan rata-rata $84,05 \%$ yang memiliki rasa cukup pedas. Hasil uji laboratorium kandungan protein tertinggi pada sampel $\mathrm{K}$ dengan penambahan cabe $0 \%$ dan rata-rata prosentase protein $20,45685 \%$.
\end{abstract}

Kata kunci : bumbu tabur, pedas, tempe

\section{Tempeh Seasoning Powder Healthy, Tasteful and Spicy For The Family}

\section{Abstract}

One of the functions of the family is to be able to meet the food and nutritional needs of the family. The protein content of the tempeh spices can complement the nutritional needs of the family at a relatively affordable price. Tempeh seasoning powder are spices whose function is to give delicious flavors to foods or snacks. The flavors and colors of the various types of sprinkles add to its special charm. The nutritional content of the chili powder is used as an addition in the manufacture of sprinkles. The purpose of this study was to determine the addition of chili powder to the sprinkles and to determine the protein content of the percentages $0 \%, 20 \%, 25 \%$, and $30 \%$ in terms of aroma, color, taste, and texture aspects. The approach method used is the experimental method due to the treatment or experiment. The experimental design used was the pretest-posttest control group design. Analyst results obtained were then analyzed statistically. To determine the nutritional content of protein using the Kjeldahl method. Based on the results of the preference test, the sample that the community likes is sample B with the addition of $25 \%$ chilies and an average of $84.05 \%$ which has a quite spicy taste. The laboratory test results of the highest protein content in sample $A$ with the addition of $0 \%$ chilli and an average protein percentage of $20.45685 \%$.

Keywords : seasoning powder, spicy, tempeh

\section{PENDAHULUAN}

Keluarga adalah unit pertama dan institusi dalam masyarakat, dimana hubungan yang terdapat di dalamnya sebagian besar sifatnya berupa hubungan- hubungan langsung. Keluarga memainkan peranan penting dalam membangun kesejahteraan, pengasuhan dan 
pendidikan dasar kepada anggota-anggota keluarga (Fahrudin, 2005). Pada semua budaya masyarakat, tanggungjawab penjagaan, perawatan dan pengasuhan anak dibebankan kepada institusi keluarga (Nock, 1992). Di lingkungan keluarga, anak akan mendapatkan kebutuhan kebutuhan yang diperlukan oleh anak, mulai dari kebutuhan jasmani seperti sandang, pangan dan papan hingga kebutuhan rohani seperti bimbingan, pendidikan, dan kasih sayang dari orang tua (Soetjiningsih, 2012).

Fungsi keluarga adalah ukuran dari bagaimana sebuah keluarga beroperasi sebagai unit dan bagaimana anggota keluarga berinteraksi satu sama lain. Fungsi keluarga mempengaruhi kapasitas kesehatan dan kesejahteraan seluruh anggota keluarga (Families, 2010). Peran keluarga menggambarkan seperangkat perilaku antar pribadi serta harapan dari keluarga tersebut, sehingga dapat dikatakan bahwa keluarga merupakan peran terpentimg yang pertama kali menyusun menu makanan kaya akan gizi.

Saat ini, Indonesia masih menghadapi tantangan besar dalam bidang gizi yaitu gizi kurang dan gizi lebih, pada masalah gizi kurang disebabkan oleh kemiskinan, kurangnya bahan pangan, kurangnya pengetahuan tentang gizi, akan tetapi masalah yang dialami dari gizi lebih kebanyakan disebaban oleh kurangnya tingkat pengetahuan tentang gizi di lapisan masyarakat (keluarga) .

Konsumsi pangan dengan gizi yang cukup dan seimbang merupakan faktor penting untuk menentukan tingkat kesehatan dan tingkat kecukupan konsumsi pangan dan gizi seseorang akan mempengharui keseimbangan perkembangan jasmani dan rohani yang bersangkutan untuk mempertahankan ketahanan pangan tingkat rumah tangga, ditetapkan rekomendasi kecukupan energi dan protein per orang / hari adalah 2.200 kilokalori dan 52 gram (Rahmadi dkk, 2013).

Tempe merupakan produk fermentasi kedelai asli dari Indonesia yang tinggi protein. Muchtadi (2010) menjelaskan bahwa proses fermentasi dalam pembuatan tempe dapat meningkatkan daya cerna protein dan kandungan beberapa macam vitamin B, selain itu zat gizi yang terkandung dalam kedelai mentah juga masih dapat dipertahankan. Nout dan Kiers (2005) menyatakan bahwa manfaat utama dari proses fermentasi kedelai adalah meningkatnya kualitas organoleptik dan kandungan gizi dibandingkan dengan bahan mentah.

Masalah utama yang dihadapi pada tempe adalah umur simpannya yang relatif pendek akibat kadar airnya yang cukup tinggi, serta adanya kapang yang terus tumbuh dan berkembang biak, menyebabkan degradasi protein dan membentuk amonia. Amonia yang terbentuk menyebabkan munculnya aroma busuk (Astawan, 2013). Oleh karena itu, pembuatan tepung merupakan alternatif pengolahan untuk memperpanjang daya tahan simpan dan daya guna tempe (Mursyid et al. 2014).

Pengolahan tempe menjadi tepung memiliki banyak manfaat, antara lain tepung tempe mudah disimpan, ataupun diolah menjadi makanan cepat saji dan dapat digunakan sebagai bahan baku pengganti tepung atau digunakan bersama tepung terigu (Soenardi, 2002). Manfaat tepung tempe yang lain adalah dapat meningkatkan kadar protein pada produk, selain itu merupakan salah satu upaya untuk mengurangi ketergantungan masyarakat akan tepung terigu. Tepung tempe dapat dijadikan sebagai pensubstitusi tepung terigu karena kandungan protein tepung tempe lebih tinggi dari tepung terigu. Selain untuk meningkatkan kadar protein tepung tempe juga dapat dimanfaatkan bagi yang alergi terhadap gluten seperti pada penderita autis .

Bumbu tabur atau seasoning powder atau bumbu perasa merupakan bumbu yang fungsinya untuk memberikan rasa pelezat pada makanan atau jajanan. Rasa dan warna pada bumbu tabur bermacam-macam jenisnya menambah daya tarik tersendiri. Jajanan yang memiliki bumbu berwarna yang mencolok membuat konsumen tertarik untuk mengkonsumsinya (Sari, 2017). 
Cabai merupakan salah satu bahan yang dapat digunakan dalam bentuk segar maupun dalam bentuk kering. Kandungan Capsaicin pada cabai membuat cabai terasa pedas. Cabai dapat diolah menjadi berbagai macam bentuk seperti cabai giling, saus cabe dan bubuk cabai. Salah satu olahan cabai adalah bubuk cabai, yang biasanya digunakan sebagai perasa pedas pada makanan. Bubuk cabe merupakan produk yang berbentuk bubuk, praktis dalam penyimpanan dan memiliki daya simpan yang lama. Sifat produk bubuk ini adalah mempunyai ukuran partikel yang sangat kecil, memilki kadar air yang sangat rendah (Surdayanti dkk, 2012).

Keju merupakan pangan serba guna yang biasanya ada pada menu sebagai perangsang selera, sebagai perangsang selera keju biasa dijumpai sebagai keju untuk pasta, keju olesan atau keju irisan. Keju sudah banyak dikenal oleh masyarakat memiliki nilai gizi yang tinggi. Citarasa keju yang memiliki aroma dan rasa yang khas dapat mencirikan suatu makanan memiliki segmentasi secara khusus (Herawati, 2011).

Pada penelitian ini, tempe dijadikan sebagai tepung tempe kemudian hasil tepung diaplikasikan pada pembuatan bumbu tabur dengan penambahan prosentase serbuk cabai $(0 \%, 20 \%, 25 \%, 39 \%)$. Pengembangan formula bumbu tabur dengan penambahan serbuk cabai dilakukan dalam upaya peningkatan kualitas bumbu tabur. Kajian ini dilakukan untuk mendapatkan komposisi serbuk cabai terbaik dalam pembuatan bumbu tabur. Parameter yang dianalisis adalah uji kesukaan. Uji kesukaan dilakukan dengan cara memberikan kuisioner kepada panelis tidak terlatih untuk mengetahui kriteria uji kesukaan pada bumbu tabur, yang meliputi rasa, warna, tekstur, aroma, dan keseluruhan. Selain itu, penelitian ini juga bertujuan untuk mengetahui kadar protein dari bumbu tabur, sehingga terciptalah bumbu tabur sehat, gurih dan pedas untuk keluarga yang kaya akan sumber protein.

\section{METODE}

Jenis penelitian ini berupa eksperimen (adanya perlakuan/percobaan). Desain eksperimen menggunakan metode pretest-posttest control group desain. Objek penelitian ini adalah bumbu tabur dari tepung tempe rasa keju pedas dengan penambahan serbuk cabai yang berbeda. Terdapat 3 jenis variabel penelitian yaitu variabel bebas, variabel terikat, dan variabel kontrol. Variabel bebas dalam penelitian ini adalah jumlah penambahan cabai merah dengan prosentase $0 \%, 20 \%, 25 \%$ dan $30 \%$. Dalam penelitian ini variabel terikatnya adalah uji kesukaan bumbu tabur terhadap panelis dengan indikator warna, rasa, aroma dan tekstur serta kandungan gizi yaitu protein. Dalam penelitian ini variabel kontrolnya adalah kondisi bahan, proses pembuatan, dan kondisi panelis. Metode pengumpulan data menggunakan penilaian subjektif yaitu uji kesukaan terhadap bumbu tabur, sedangkan penilaian objektif dengan uji Laboratorium. (1) Uji kesukaan, untuk mengetahui tingkat kesukaan panelis terhadap bumbu tabur dari tepung tempe rasa keju pedas. Uji kesukaan dilakukan dengan menggunakan panelis tidak terlatih sebanyak 80 orang. (2) Uji kandungan protein dilakukan di Laboratorium Chem-Mix Pratama Yogyakarta.

\section{Pembuatan Tepung Tempe}

Tempe kedelai segar yang diiris tipis, dikukus dalam uap air panas pada suhu $1000 \mathrm{C}$ selama 10 menit, kemudian tiriskan untuk mengurangi kadar air dan dinginkan pada suhu kamar. Selanjutnya dilakukan pengeringan dengan oven pengering atau dengan sinar matahari \pm 2 hari penjemuran. Tempe kering kemudian diblander. Tepung yang dihasilkan kemudian diayak dengan ayakan 80 mesh, dan pengayakan dilakukan berulang-ulang sampai memperoleh tepung tempe yang homogen (Rahmawati dan Sumiyati, 2000:4).

Pada penelitian ini, proses pembuatan tepung tempe yaitu dengan menggunakan tempe segar, kemudian tempe diiris setebal 0,22 mm, lalu dikukus dengan suhu $1050 \mathrm{c}$ selama 20 menit, kemudian ditiriskan pada tampah untukmengurangi kadar air pada suhu kamar. Selanjutnya dilakukan pengeringan dengan suhu $60^{\circ} \mathrm{C}$ selama $5 \mathrm{jam}$. Tempe kering 
kemudian diblender. Tepung yang dihasilkan kemudian diayak 100 mesh, dan pengayakan dilakukan berulang- ulang sampai memperoleh tepung tempe yang homogen.

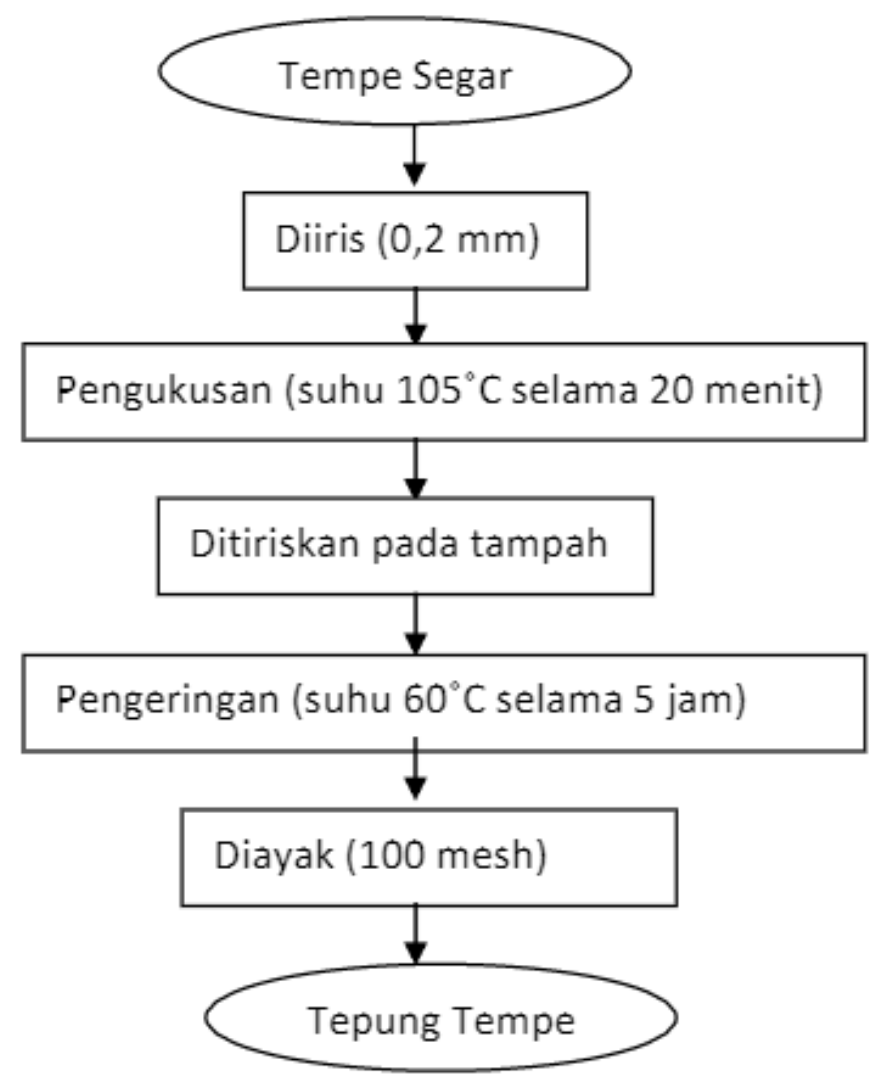

Gambar 1. Diagram alir proses pembuatan tepung tempe

\section{Pembuatan Serbuk Cabai}

Cabai bubuk dibuat dari cabai yang telah dikeringkan, dan dilakukan penepungan untuk memperoleh bentuk seperti bubuk. Penggilingan dilakukan dengan menggunakan alat penggiling sederhana, sesuai tingkat kehalusan yang diinginkan. Cabai bubuk yang telah di olah, dikemas dengan menggunakan botol plastik, toples plastik atau aluminium foil. Cabai bubuk dapat di manfaatkan sebagai bumbu makanan seperti nasi goreng, mie rebus, gulai dan seasoning untuk aneka kudapan (Badan Litbag Pertanian Sulawesi Selatan, 2012). Cabai yang sering dijadikan dalam bentuk bubuk adalah cabai besar (Gardjito, 2013 : 32).

\section{HASIL DAN PEMBAHASAN}

Hasil penelitian membahas hasil analisis data yang disajikan dalam rangka menjawab rumusan permasalahan meliputi data tingkat kesukaan panelis terhadap bumbu tabur dari tepung tempe rasa keju pedas dengan penambahan prosentase cabai yang berbeda yaitu $0 \%, 20 \%, 25 \%$, dan $30 \%$, serta data kandungan protein pada bumbu tabur dari tepung tempe rasa keju pedas. Variasi sampel yang digunakan penelitian ini berjumlah 4 sampel yaitu sampel K (bumbu tabur kontrol), A (bumbu tabur dengan penambahan cabai bubuk $20 \%$ ) B (bumbu tabur dengan penambahan cabai bubuk 25\%), C (bumbu tabur dengan penambahan cabai bubuk 30\%). 


\section{Uji Kesukaan}

Untuk mengetahui tingkat kesukaan panelis digunkan uji hedonik dengan bertujuan untuk mengetahui tanggapan panelis terhadap bumbu tabur dari tepung tempe rasa keju pedas dengan parameter rasa, aroma, warna, tekstur dan keseluruhan.

Rasa. Rasa merupakan faktor yang paling penting daalm menentukan keputusan bagi konsumen untuk menerima atau menolak suatu produk pangan. Meskipun parameter lain nilainya baik, tapi jika rasa tidak enak atau tidak disukai maka produk akan ditolak. Ada empat jenis rasa dasar yang dikenali manusia yaitu asin, asam, manis dan pahit. Sedangkan rasa lainnya merupakan perpaduan dari keempat rasa tersebut.

Penambahan serbuk cabai yang bervariasi bertujuan untuk mendapatkan formula yang disukai panrlis. Cabai juga berperan dalam mempertahankan mutu produk pangan akibat kerusakan seperti ketengikan, perubahan nilai gizi, perubahan warna dan aroma serta kerusakan fisisk lain pada produk pangan. Senyawa aktif kimia yang terdapat pada cabai adalah capsaicin (minyak atsiri), yang tersimpan dalam daging buah, biji atau dalam tempat melekatnya biji.

Capsaicin berperan sebagai bakterisida dan fungisida. Capsaicin termasuk dalam golongan kapsasinoid, yaitu zat pedas yang terdapat pada tumbuh- tumbuhan, bersifat larut dalam lemak (non polar) dan mudah teroksidasi dalam penyimpanan.

Hasil penilaian uji kesukaan oleh panelis tidak terlatih pada indikator rasa (pedas gurih) dari keempat sampel bumbu tabur yaitu sampel $\mathrm{K}$ dengan cabe $0 \%$ memiliki retara 3,0 , sampel A dengan cabe $20 \%$ memiliki retara 3,627 , sampel B dengan cabe $25 \%$ memiliki retara 3,7375 dan sampel $C$ dengan cabe $30 \%$ memiliki retara 3,4125. Rasa pedas gurih pada sampel $\mathrm{K}$ dengan cabe $0 \%$ cukup disukai masyarakat, sedangkan rasa pedas gurih pada sampel A dengan cabe $20 \%$, sampel B dengan cabe $25 \%$ dan sampel C dengan cabe $30 \%$ disukai oleh masyarakat.

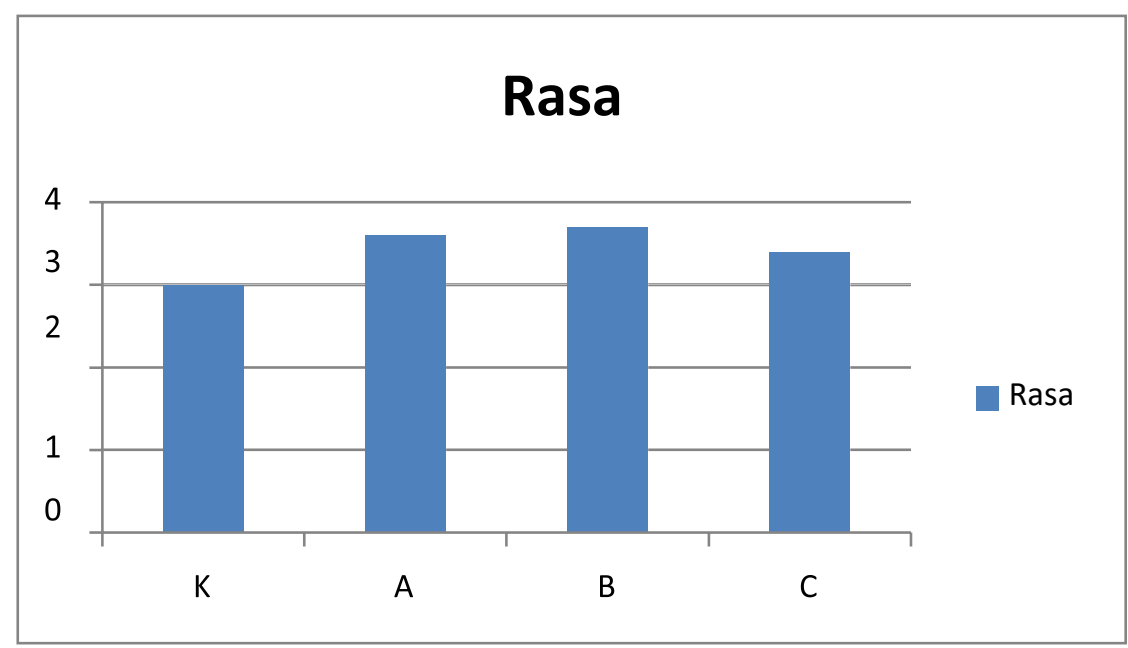

Gambar 1. Nilai rata-rata rasa bumbu tabur

Keterangan :

$\mathrm{K}=$ Bumbu tabur kontrol, $100 \mathrm{gr}$ tepung tempe

$A=$ Bumbu tabur dengan presentase cabe $20 \%$

$\mathrm{B}=$ Bumbu tabur dengan presentase cabe $25 \%$

$\mathrm{C}=$ Bumbu tabur dengan presentase cabe $30 \%$ 
Aroma. Aroma mempunyai peranan yang sangat penting dalam penentuan derajat penilaian dan kualitas suatu bahan. Selain bentuk dan warna, aroma atau aroma akan berpengaruh dan menjadi perhatian utama. Setelah bau diterima maka penentuan selanjutnya adalah citarasa disamping teksturnya.

Hasil penilaian uji kesukaan oleh panelis tidak terlatih pada indikator aroma (khas tempe/tidak langu) dari keempat sampel bumbu tabur disukai masyarakat. Aroma khas tempe pada sampel $\mathrm{K}$ dengan cabe $0 \%$ memiliki retara 3,5, sampel A dengan cabe $20 \%$ memiliki retara 3,91, sampel B dengan cabe $25 \%$ memiliki retara 4,07 dan sampel $C$ dengan cabe $30 \%$ memiliki retara 3,65. Aroma khas tempe/tidak langu yang palling banyak disukai masyarakat pada sampel B dengan presentase cabe $25 \%$.

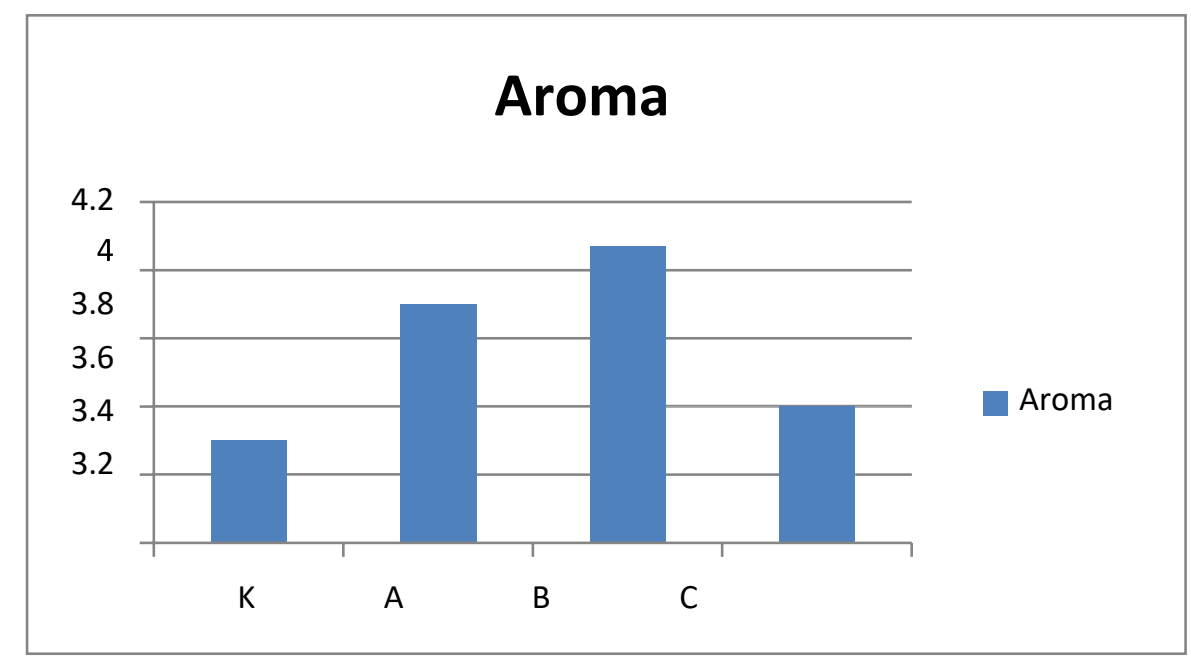

Gambar 2. Nilai rata-rata aroma bumbu tabur

Keterangan :

$\mathrm{K}=$ Bumbu tabur kontrol, $100 \mathrm{gr}$ tepung tempe

$A=$ Bumbu tabur dengan presentase cabe $20 \%$

$B=$ Bumbu tabur dengan presentase cabe $25 \%$

$\mathrm{C}=$ Bumbu tabur dengan presentase cabe $30 \%$

Tekstur. Tekstur merupakan sensasi tekanan yang dapat diamati dengan mulut (pada waktu digigit, dikunyah dan ditelan) ataupun dengan perabaan jari. Tekstur juga merupakan faktor mutu yang terlihat nyata dan biasanya dapat diukur serta diawasi dengan mudah karena pada umumnya seluruh permukaan bahan kelihatan dari luar.

Parameter bumbu tabur yang halus merupakan salah satu faktor yang dapat berpengaruh terhadap mutu bumbu tabur yaitu tekstur. Tekstur halus didapatkan dari bubuk bahan-bahan bumbu tabur, kemudian dicampur menjadi satu sehingga mendapatkan tekstur bumbu tabur yang halus.

Hasil uji kesukaan pada indikator tekstur (halus) dari keempat sampel bumbu tabur disukai masyarakat. Tekstur (halus) pada sampel $\mathrm{K}$ dengan cabe $0 \%$ memiliki retara 3,825, sampel A dengan cabe $20 \%$ memiliki retara 4,03 , sampel B dengan cabe $25 \%$ memiliki retara 4,17 dan sampel $C$ dengan cabe $30 \%$ memiliki retara 3,87. Tekstur (halus) yang paling banyak disukai masyarakat pada sampel B dengan presentase cabe $25 \%$. 


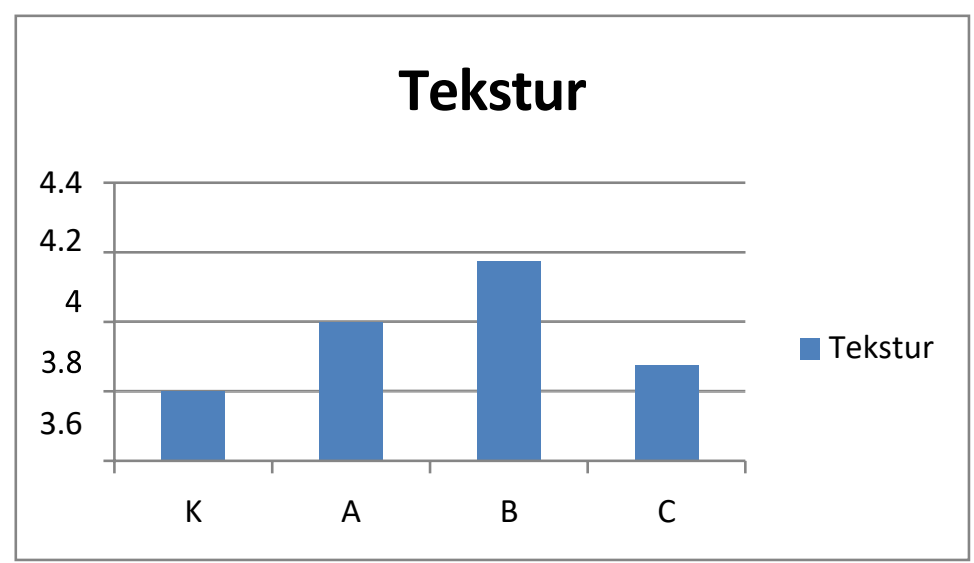

Gambar 3. Nilai rata-rata tekstur bumbu tabur

Keterangan :

$\mathrm{K}=$ Bumbu tabur kontrol, $100 \mathrm{gr}$ tepung tempe

$A=$ Bumbu tabur dengan presentase cabe $20 \%$

$\mathrm{B}=$ Bumbu tabur dengan presentase cabe $25 \%$

$\mathrm{C}=$ Bumbu tabur dengan presentase cabe $30 \%$

Warna. Warna merupakan komponen yang sangat penting untuk menentukan kualitas atau derajat penerimaan suatu bahan pangan. Suatu bahan pangan meskipun dinilai sangat enak dan teksturnya baik, tetapi memilki warna yang kurang sedap dipandang atau memberikan kesan yang menyimpang dari warna yang seharusnya, maka tidak layak dikonsumsi. Penentuan mutu suatu bahan pangan pada umumnya tergantung pada warna, karena warna tampil terdahulu.

Hasil penilaian uji kesukaan oleh panelis tidak terlatih pada indikator warna dari keempat sampel bumbu tabur sangat disukai masyarakat. Pada sampel $\mathrm{K}$ dengan cabe $0 \%$ memiliki retara 4,212, sampel A dengan cabe $20 \%$ memiliki retara 4,41 , sampel B dengan cabe $25 \%$ memiliki retara 4,525 dan sampel $C$ dengan cabe $30 \%$ memiliki retara 4,6265, sehingga warna cokelat kemerahan dipandang sangat menarik oleh masyarakat.

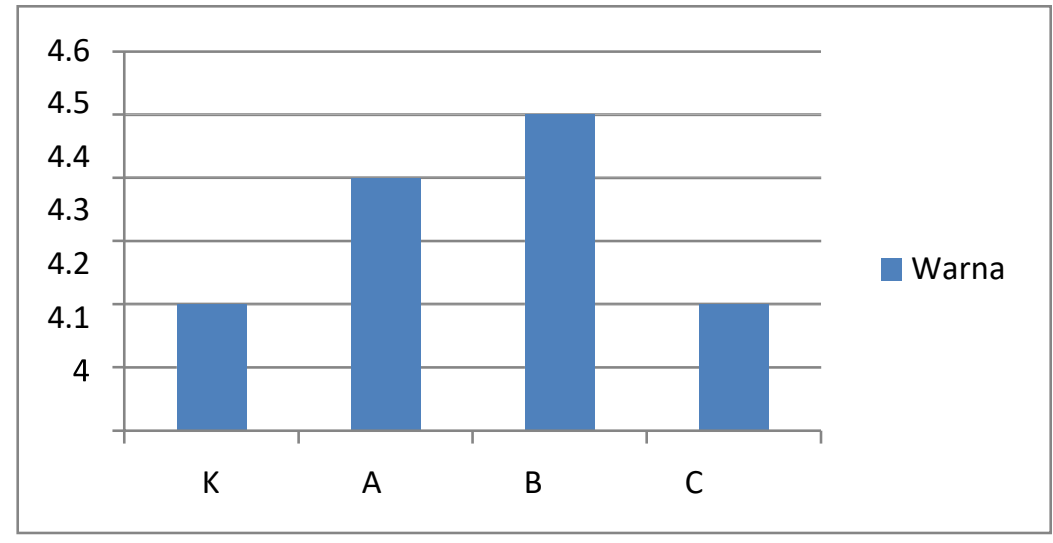

Gambar 4. Nilai rata-rata warna bumbu tabur

Keterangan :

$\mathrm{K}=$ Bumbu tabur kontrol, $100 \mathrm{gr}$ tepung tempe

$A=$ Bumbu tabur dengan presentase cabe $20 \%$

$B=$ Bumbu tabur dengan presentase cabe $25 \%$

$\mathrm{C}=$ Bumbu tabur dengan presentase cabe $30 \%$ 
Keseluruhan. Dari keseluruhan sampel kesukaan, sampel B dengan cabe $25 \%$ memiliki rerata tertinggi yaitu 4,50 , sedangkan sampel $\mathrm{K}$ dengan cabe $0 \%$ memiliki retara 4,3875 , sampel A dengan cabe $20 \%$ memiliki rerata 4,4375 , dan sampel $\mathrm{C}$ dengan cabe $30 \%$ memiliki rerata 4,375. Keempat sampel tersebut termasuk dalam kriteria sangat disukai masyarakat.

Berdasarkan uji kesukaan terhadap pembuatan bumbu tabur dari tepung tempe rasa keju pedas meliputi aspek keseluruhan, warna, aroma, tekstur dan rasa yang dilakukan oleh 80 orang panelis tidak terlatih. Secara keseluruhan sampel yang sangat disukai oleh masyarakat adalah sampel B dengan cabe $25 \%$ dan memiliki rata-rata prosentase tertinggi yaitu $84,05 \%$ dengan kriteria sangat suka.

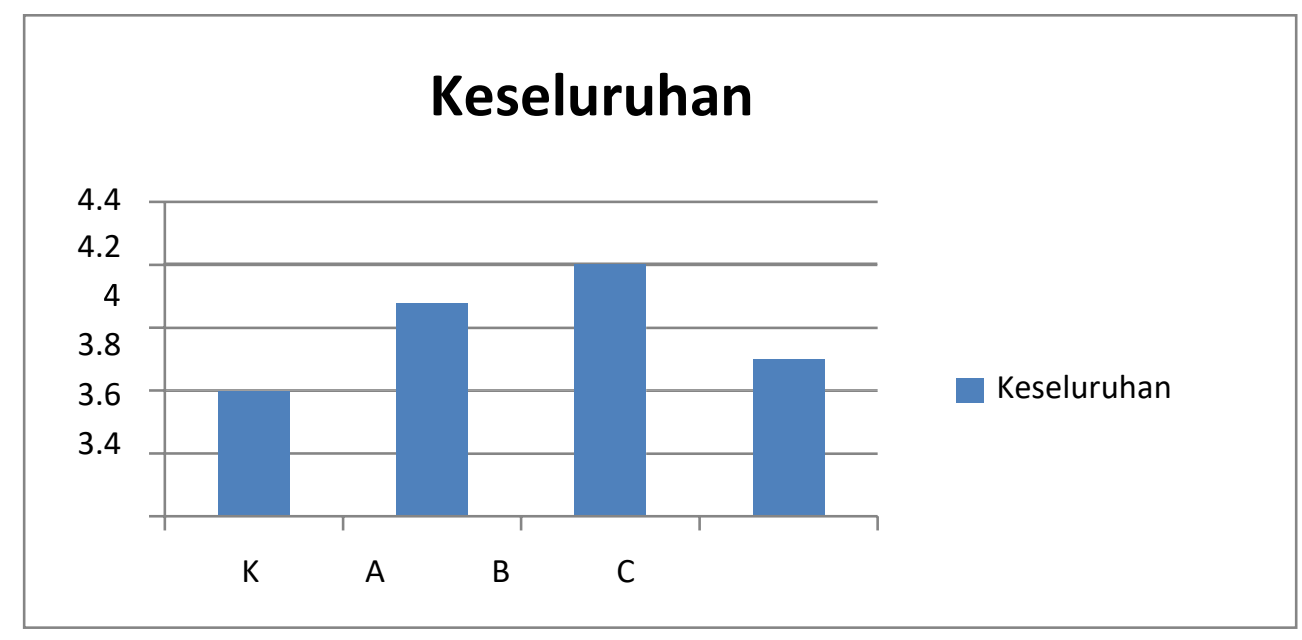

Gambar 5. Nilai rata-rata keseluruhan bumbu tabur

Keterangan :

$\mathrm{K}=$ Bumbu tabur kontrol, $100 \mathrm{gr}$ tepung tempe

$A=$ Bumbu tabur dengan presentase cabe $20 \%$

$\mathrm{B}=$ Bumbu tabur dengan presentase cabe $25 \%$

$\mathrm{C}=$ Bumbu tabur dengan presentase cabe $30 \%$

\section{Kandungan Protein pada Bumbu Tabur}

Fungsi utama protein bagi tubuh ialah untuk membentuk jaringan baru dan mempertahankan jaringan yang telah ada. Protein juga digunakan sebagai bahan bakar apabila keperluan energi tubuh tidak terpenuhi oleh karbohidrat dan lemak. Protein ikut pula mengatur berbagai proses tubuh, baik langsung maupun tidak langsung dengan membentuk zat-zat pengatur proses dalam tubuh. Protein mengatur keseimbangan cairan dalam jaringan dan pembuluh darah (Winarno, 1991:50). Serat makanan merupakan bagian dari makanan yang tidak dapat dihidrolisis oleh enzim pencernaan, akan tetapi serat dapat dipakai sebagai obat sembelit, gangguan pencernaan dan mengurangi gangguan buang air besar pada tubuh.

Hasil tersebut diketahui bahwa tedapat kenaikan kandungan protein dari empat sampel bumbu tabur kontrol, bumbu tabur dengan prosentase cabe $20 \%$, bumbu tabur dengan prosentase cabe $25 \%$, dan bumbu tabur dengan prosentase cabe $30 \%$. Sampel bumbu tabur kontrol memiliki rata-rata kandungan protein yaitu $20,45685 \%$. Sampel bumbu tabur dengan prosentase cabe $20 \%$ memiliki rata-rata kandungan protein yaitu $19,41555 \%$, bumbu tabur dengan prosentase cabe $25 \%$ memiliki rata-rata kandungan protein yaitu $17,02215 \%$ dan bumbu tabur dengan prosentase cabe $30 \%$ memiliki rata-rata kandungan protein yaitu $16,59945 \%$ 


\section{SIMPULAN DAN SARAN}

Dari hasil penelitian dapat disimpulkan bahwa tingkat kesukaan panelis terhadap penambahan serbuk cabai dengan presentase yang berbeda pada bumbu tabur dari tepung tempe rasa keju pedas memberikan perbedaan terhadap warna, aroma, tekstur, rasa dan secara keseluruhan bumbu tabur. Dari keseluruhan sampel kesukaan, sampel B dengan cabe $25 \%$ memiliki rerata tertinggi yaitu 4,50 . sedangkan sampel $\mathrm{K}$ dengan cabe $0 \%$ memiliki retara 4,3875 , sampel $A$ dengan cabe $20 \%$ memiliki rerata 4,4375 , dan sampel $C$ dengan cabe $30 \%$ memiliki rerata 4,375 . Penambahan serbuk cabai $25 \%$ berdasarkan uji hedonik untuk parameter penerimaan keseluruhan memberikan hasil terbaik. Sampel bumbu tabur kontrol memiliki rata-rata kandungan protein yaitu $20,45685 \%$. Sampel bumbu tabur dengan prosentase cabe $20 \%$ memiliki rata-rata kandungan protein yaitu $19,41555 \%$, bumbu tabur dengan prosentase cabe $25 \%$ memiliki rata-rata kandungan protein yaitu $17,02215 \%$ dan bumbu tabur dengan prosentase cabe $30 \%$ memiliki rata-rata kandungan protein yaitu $16,59945 \%$. Bumbu tabur dengan kandungan protein tertinggi terdapat pada sampe kontrol dengan penambahan cabe bubuk $0 \%$ yaitu dengan rata-rata $20,45685 \%$. Diharapkan bumbu tabur dari tepung tempe rasa keju pedas ini dapat menjadi pelengkap dalam pemenuhan gizi keluarga.

\section{DAFTAR PUSTAKA}

Astawan M, Wresdiyati T, Widowati S, Bintari SH, Ichsani N. (2013). Karakteristik fisikokimia dan sifat fungsional tempe yang dihasilkan dari berbagai varietas kedelai. Pangan 22(3):241-252.

Fahrudin, A. (2005). Ketahanan institusi keluarga dan kesejahteraan anak. Makalah disajikan dalam Workshop Penguatan Institusi Keluarga anjuran Pusat Kajian Perempuan dan Keluarga, STKS Bandung. 21 September 2005.

Families, C.a.S.S., (2010). The State of Victoria's Children 2010. Victoria: Families, Communities and Social Support. p.257.

Garjito, M., (2013). Bumbu, penyedap, dan penyerta masakan Indonesia. Gramedia Pustaka Utama.

Herawati, H., (2011). Peluang Pemanfaatan Tapioka Termodifikasi Sebagai Fat Replacer pada Keju Rendah Lemak. In Seminar Nasional Teknologi Peternakan Dan Veteriner (pp. 411419).

Maulina, A. (2015). Eksperimen Pembuatan Cake Subtitusi Tepung Tempe (Doctoral dissertation, UNIVERSITAS NEGERI SEMARANG).

Mursyid, Astawan M, Muchtadi D, Wresdiyati T, Widowati S, Bintari SH, Suwarno M. (2014). Evaluasi nilai gizi protein tepung tempe yang terbuat dari varietas kedelai impor dan lokal. Pangan 23(1):33-41.

Nout, M. J. R., \& Kiers, J. L. (2005). Tempe fermentation, innovation and functionality: update into the third millenium. Journal of Applied Microbiology, 98(4), 789-805. https://doi.org/10.1111/i.1365-2672.2004.02471.x

Rahmadi. Toto Sudargo. Agus Wijanarka. (2013). Perilaku Sadar Gizi dan Ketahanan Pangan Keluarga Serta Hubungannya Dengan Status Gizi Balita Di Kabupaten Tanah Laut, Kalimantan Selatan. Jurnal Gizi Dan Dietetik Indonesia. Kalimantan Selatan.

Rahmawati, M. dan F. Sumiyati. (2000). Tepung Tempe. Jakarta: Lembaga Ilmu Pengetahuan Indonesia. 
Sari Ratih Pratiwi. (2017). Identifikasi Dan Penetapan Kadar Rhodamin B Pada Kue Berwarna Merah Di Pasar Antasari Kota Banjarmasin, Jurnal IImiah Manuntung (1), 75-84, Vol:1 Issue 2017

Soenardi.T., (2002)., Makanan Alternatif Untuk Ketahanan Pangan Nsional., Penerbit Buku Kompas., Jakarta.

Soetjiningsih., (2012), Tumbuh Kembang Anak. Jakarta: Penerbit Buku Kedokteran EGC. Almatsier S., (2010). Prinsip Dasar Ilmu Gizi. Jakarta: Penerbit PT Gramedia Pustaka Utama.

Sudaryati, L \& Donny E.H. (2012). Pembuatan Bubuk Cabai Merah Menggunakan Variasi Jenis Cabe dan Metode Pengeringan. FTI UPN.

Susilawati, S. (2018). Analisis Tingkat Pengetahuan Pedagang dalam Penggunaan Kandungan Zat Pewarna Merah pada Bubuk Cabai dalam Makanan Jajanan di Kelurahan Tembung Kecamatan Medan Tembung Tahun 2018. Global Healt Science (GHS), 3(4), 394-399.

Wahidin, U. (2017). Peran strategis keluarga dalam pendidikan anak. Edukasi Islami: Jurnal Pendidikan Islam, 1(02). 